\title{
Microcomputer Applications in Measurement Systems
}




\author{
Macmillan titles of interest to engineers \\ Boxer Work Out Fluid Mechanics \\ Boxer Work Out Thermodynamics \\ Drabble Work Out Dynamics \\ Hall Polymer Materials, 2nd edition \\ Hull and John Non-Destructive Testing \\ Jackson and Dhir Civil Engineering Materials, 4th edition \\ John Work Out Engineering Materials \\ Mosley and Bungey Reinforced Concrete Design, 4th edition \\ Mosley and Hulse Reinforced Concrete Design by Computer \\ Simonson Engineering Heat Transfer, 2nd edition \\ Spencer Fundamental Structural Analysis \\ Stone Introduction to Internal Combustion Engines \\ Stone Motor Vehicle Fuel Economy \\ Turner Instrumentation for Engineers \\ Uren and Price Surveying for Engineers \\ Foundations of Engineering Series \\ Drabble Dynamics \\ Hulse and Cain Structural Mechanics \\ Powell Electromagnetism \\ Silvester Electric Circuits
}




\title{
Microcomputer Applications
}

\section{in \\ Measurement Systems}

\author{
C. J. Fraser \\ BSc, PhD, CEng, MIMechE, MlnstPet \\ Reader in Mechanical Engineering \\ Dundee Institute of Technology \\ J. S. Milne \\ BSc, CEng, FIMechE \\ Senior Lecturer in Mechanical Engineering \\ Dundee Institute of Technology
}

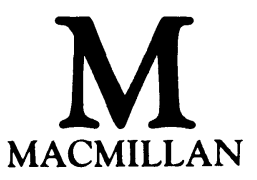


(c) C. J. Fraser and J. S. Milne 1990

All rights reserved. No reproduction, copy or transmission of this publication may be made without written permission.

No paragraph of this publication may be reproduced, copied or transmitted save with written permission or in accordance with the provisions of the Copyright, Designs and Patents Act 1988 or under the terms of any licence permitting limited copying issued by the Copyright Licensing Agency, 33-4 Alfred Place, London WC1E 7DP.

Any person who does any unauthorised act in relation to this publication may be liable to criminal prosecution and civil claims for damages.

First published 1990

Published by

MACMILLAN EDUCATION LTD

Houndmills, Basingstoke, Hampshire RG21 2XS

and London

Companies and representatives

throughout the world

British Library Cataloguing in Publication Data

Fraser, C. J.

Microcomputer applications in measurement systems.

1. Science. Experiments. Scientific experiments.

Applications of microcomputer systems

I. Title II. Milne, J. S.

$502^{\prime} .8^{\prime} 5404$

ISBN 978-0-333-51838-0 ISBN 978-1-349-20800-5 (eBook)

DOI 10.1007/978-1-349-20800-5 


\section{Contents}

Preface

viii

Acknowledgements

$\mathbf{x}$

Notation

$\mathrm{xi}$

1 The Engineering Laboratory

1.1 The need for experimentation

1.2 Overview of the experimental method

1.3 Impact of the new technology in the engineering laboratory 3

1.4 Towards the automated laboratory 4

1.5 Concluding remarks

2 Measurement of Primary Data 6

$\begin{array}{ll}2.1 \text { Analogue and digital transducers } & 6\end{array}$

$\begin{array}{ll}2.2 \text { Measurement applications } & 8\end{array}$

$\begin{array}{lll}2.3 & \text { Strain gauge applications } & 26\end{array}$

2.4 Signal conditioning - the operational amplifier 35

$\begin{array}{lll}2.5 & \text { Filters and buffers } & 38\end{array}$

$\begin{array}{ll}2.6 \text { Calibration, curve fitting } & 47\end{array}$

$\begin{array}{ll}\text { Exercises } & 47\end{array}$

References $\quad 49$

3 Error Accountability $\quad \mathbf{5 0}$

3.1 Errors in experimental measurements $\quad 50$

$\begin{array}{ll}3.2 \text { Uncertainty estimating } & 50\end{array}$ 
vi CONTENTS

3.3 Digital uncertainty $\quad 51$

$\begin{array}{lll}3.4 & \text { Error analysis } & 54\end{array}$

$\begin{array}{ll}3.5 & \text { Representation of uncertainty } \\ \end{array}$

$\begin{array}{ll}\text { Exercises } & 60\end{array}$

$\begin{array}{ll}\text { References } & 63\end{array}$

4 High and Low Level Programming 64

4.1 Number systems $\quad 64$

$\begin{array}{lll}4.2 \text { Gray code } & 70\end{array}$

$\begin{array}{lll}4.3 & \text { ASCII code } & 71\end{array}$

4.4 Elements of BASIC $\quad 72$

$\begin{array}{lll}4.5 & \text { Flow diagrams } & 77\end{array}$

$\begin{array}{lll}4.6 & \text { Elements of assembly language } & 78\end{array}$

4.7 Program development and structure $\quad 84$

$\begin{array}{ll}\text { Exercises } & 86\end{array}$

$\begin{array}{ll}\text { References } & 87\end{array}$

5 Microprocessor Technology $\quad 89$

$\begin{array}{llr}5.1 & \text { System architecture } & 89\end{array}$

5.2 Memory devices $\quad 91$

$\begin{array}{lll}5.3 \mathrm{I} / 0 \text { structure } & 93\end{array}$

$\begin{array}{lll}5.4 & \text { Bus structure } & 100\end{array}$

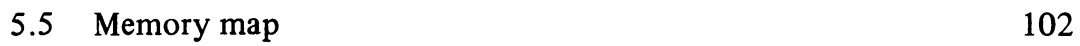

5.6 Communication standards $\quad 104$

$\begin{array}{ll}\text { References } & 107\end{array}$

6 Data Acquisition and Control 108

$\begin{array}{lll}6.1 & \mathrm{I} / \mathrm{O} \text { communication } & 108\end{array}$

$\begin{array}{ll}\text { 6.2 Digital interfacing } & 111\end{array}$

$\begin{array}{ll}6.3 \text { Analogue interfacing } & 114\end{array}$

$\begin{array}{ll}6.4 \text { Multiplexing } & 122\end{array}$

$\begin{array}{lll}6.5 & \text { Digital sampling } & 124\end{array}$

$\begin{array}{lll}6.6 & \text { Digital control } & 126\end{array}$

$\begin{array}{lll}6.7 & \text { Peripheral systems, data logging } & 138\end{array}$

6.8 The virtual instrument concept 139

$\begin{array}{ll}\text { References } & 140\end{array}$

7 Data Acquisition with the BBC Microcomputer 141

7.1 The ADVAL command in BBC BASIC 141

7.2 The BBC microcomputer user port 145

7.3 Fast continuous data acquisition on the BBC microcomputer 147 
$\begin{array}{ll}\text { Exercises } & 150\end{array}$

$\begin{array}{ll}\text { References } & 151\end{array}$

$8 \quad$ IBM-PC and Compatibles $\quad 152$

8.1 16-bit microcomputers 152

8.2 BASIC on 16-bit microcomputers 153

$\begin{array}{lll}8.3 & \text { MS-DOS } & 154\end{array}$

8.4 Data acquisition and control on an IBM-PC or compatible 156

8.5 Programming the 8086/8088 for fast data acquisition 160

8.6 Compiled BASIC, assemblers and linkers 169

8.7 An application in fluid dynamics $\quad 171$

$\begin{array}{ll}\text { Exercises } & 176\end{array}$

$\begin{array}{ll}\text { References } & 177\end{array}$

9 Data Handling and Display 179

$\begin{array}{lll}9.1 & \text { Data input and output } & 179\end{array}$

9.2 Formatted output in BASIC 181

$\begin{array}{lll}9.3 & \text { Computer graphics } & 185\end{array}$

9.4 Hard copy output, printer control codes 198

9.5 Disc file handling, data storage and retrieval 200

96 A simple virtual instrument 203

$\begin{array}{lll}9.7 & \text { System monitoring } & 204\end{array}$

$\begin{array}{ll}\text { Exercises } & 208\end{array}$

$\begin{array}{ll}\text { References } & 211\end{array}$

10 Applications $\quad 212$

10.1 Studies of a vibrating cantilever 212

10.2 Internal combustion engine indicator 216

10.3 A microcomputer-based test facility for boiling heat transfer studies 223

10.4 Digital control of a d.c. motor 229

$\begin{array}{ll}\text { References } & 235\end{array}$

Appendix I: Polynomial Curve Fitting - Method of Least Squares 236

Appendix II: Instruction Set for the 6502 Microprocessor 242

Appendix III: Glossary of Terms 246

Appendix IV: Hexadecimal Conversion Table 249

$\begin{array}{ll}\text { Index } & 250\end{array}$ 


\section{Preface}

During the previous decade the most significant improvements in instrumentation and measurement have been centred round the development of microelectronic devices. The modern engineering laboratory displays an ever increasing range of microprocessor-based products: supplementing various instrumentation and primary sensors, and providing a new dimension of intelligence and control in engineering measurement systems. Information technology in the laboratory has removed the tedium associated with the data-taking process. Modern systems incorporating acquisition, logging, analysis and presentation of data are rapidly becoming the rule, as opposed to the exception. Microcomputers are therefore becoming increasingly evident in research and general experimental environments and undoubtedly they will continue to exert a growing influence in the enhancement of the basic instrumentation systems of the future. The importance of the application of microcomputers in experimentation has grown to the extent that an introductory text covering the fundamental principles would now seem to be particularly warranted.

To the uninitiated, a full understanding of the microcomputer-based experimental test facility would apparently demand a detailed knowledge of instrumentation, micro-electronics, high and low level computer programming, computer architecture, the experimental method and control engineering. With such an extensive range of sub-topics to be mastered, the task of familiarisation might seem daunting to all but the most determined. This however is not the case, since although a basic knowledge is certainly required in all of the above areas, all-round in-depth expertise is not. Against this backdrop, the scope of this text is to provide a foundation for the application of the new technology in the experimental environment. The text therefore covers all of the fundamental concepts within each of the sub-topics to a sufficient depth. This should enable the readers confidently to develop their own custom-built computerised dataacquisition and control systems and subsequently to use these systems to their 
fullest advantage. Detailed expositions of the finer points are omitted, although the level which is covered will provide readers with a sound foundation upon which to develop their confidence in any of the specialist associated areas. An adequate number of references to the more specialist books are included as an aid to this development.

The book is intended primarily for students following a B Eng or a Higher National Diploma course in Engineering, but should prove useful to other science students who have a major element of experimentation incorporated in their courses. Research students about to develop an automated, or partially automated, experimental test facility may find the text of particular relevance. As an introductory text to a very broad based subject, the book should also prove useful to students following the new technology courses which are being introduced in a number of secondary school syllabuses.

Numerous full worked examples are included to lead the reader onto the more complex situations and gradually to instill confidence in the use of a microcomputer for the acquisition, reduction, analysis, storage and finally the presentation of experimental data. In addition, digital control strategies are included to give a balanced coverage of the utilisation of the microcomputer in the modern experimental test facility.

It is assumed that students will be studying concurrently, or have studied, a course in computer programming in some or other dialect of BASIC. Many of the examples and illustrative material are particular to the $\mathrm{BBC}$ microcomputer, with the 6502 microprocessor, or to the IBM-PC and compatibles with the 8088, or 8086 , microprocessor. In this manner we hope to encompass as wide a range of microcomputer hardware, relevant to the needs of industry and educational establishments alike.

Wherever possible, the semi-conductor devices and various other integrated circuits are referred to in the text by their generic type numbers. For the added benefit of UK readers, the equivalent RS Components Ltd stock reference numbers are also quoted.

Most of the programs presented, with the exception of the very short ones, are actual machine listings of working code. In this way we hope to have minimised any errors in transcription of the code. 


\section{Acknowledgements}

In the preparation of this book we have been fortunate to have had the encouragement and assistance of many of our colleagues in the department of mechanical engineering. Our students, past and present, have contributed in no uncertain terms to the contents herein through their commendable efforts in project investigations and research activities. To them we owe a special vote of thanks.

We are also very fortunate to have had the very able services of messrs Ken Rusk and Bob Greig who have often transformed our scribbled and whimsical notions into quality hardware.

The support of Macmillan Education is gratefully acknowledged and particular thanks are also due to the reviewers, for their astute guidance in the preparation of the manuscript.

Lastly we would thank our wives, Ann and Isabel, for their unstinting faith that we would get it right eventually.

Dundee, 1989

C. J. Fraser

J. S. Milne 


\section{Notation}

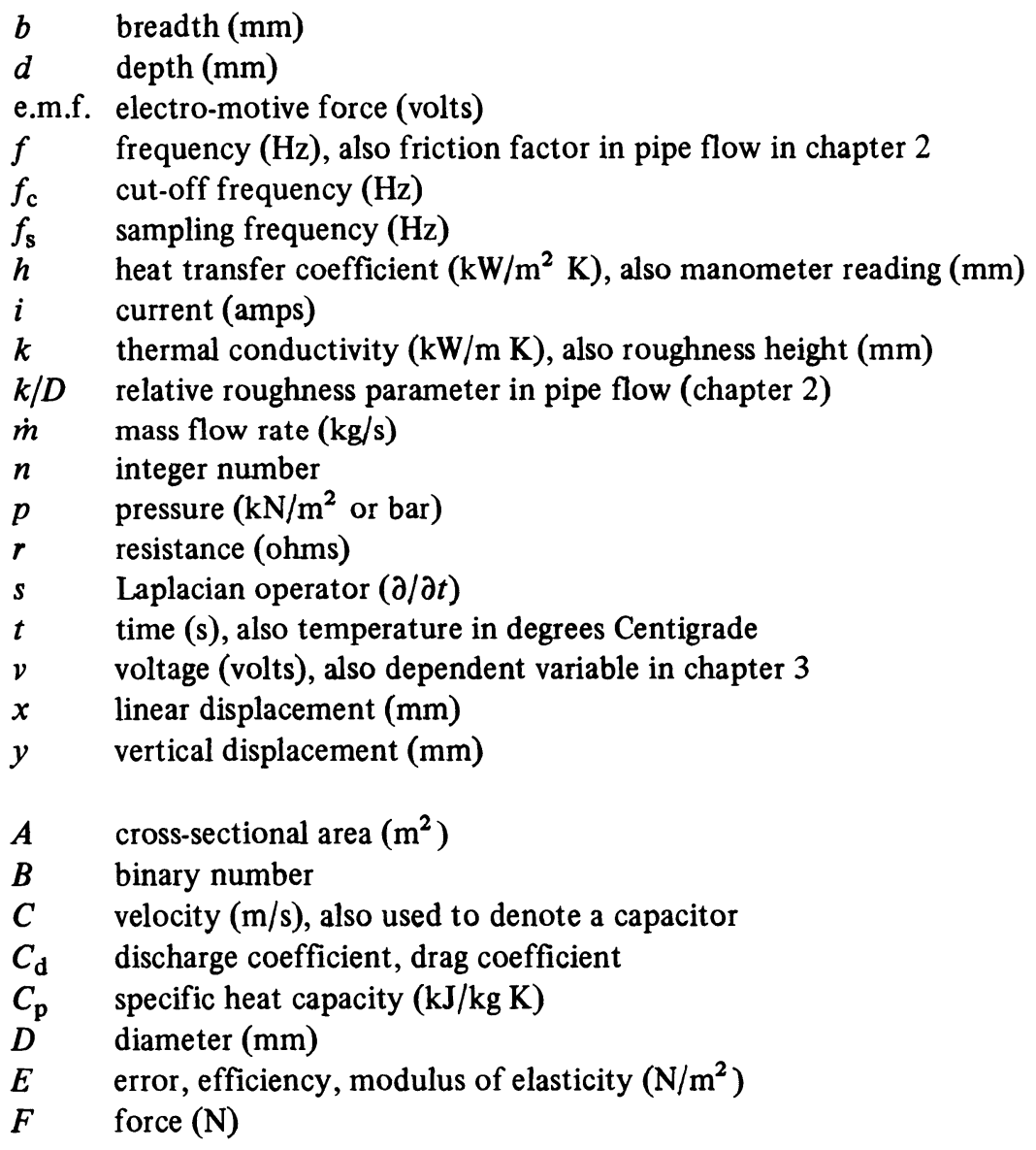


$G \quad$ gauge factor, Gray number, also used to denote a strain gauge

$H \quad$ head (m)

I current (amps)

$K \quad$ calibration constant, gain

$L \quad$ length (m)

$M \quad$ arithmetic mean, mass (kg)

$N \quad$ rotational speed (rev/min)

$\mathrm{Nu} \quad$ Nusselt number

$O$ observation, reading

$P \quad$ dependent variable

$Q \quad$ flow rate (litres/s)

$R$ resistance (ohms), also damping factor in chapter 8

$R_{0} \quad$ resistance at zero degrees Centigrade

$\boldsymbol{R}_{\mathbf{i}} \quad$ internal resistance (ohms)

$R e \quad$ Reynolds number

$S \quad$ spring stiffness $(\mathrm{N} / \mathrm{m})$

$T$ torque $(\mathrm{N} \mathrm{m})$, also temperature in degrees Kelvin or Centigrade as specified in the text

$T^{\prime} \quad$ percentage turbulence

$T_{\mathrm{d}} \quad$ derivative time constant

$T_{\mathrm{i}} \quad$ integral time constant

$U$ mean velocity $(\mathrm{m} / \mathrm{s})$

$V \quad$ voltage (volts)

$V_{\mathbf{i}} \quad$ input voltage (volts)

$V_{\mathrm{o}}$ output voltage (volts)

$W \quad \operatorname{load}(\mathrm{N})$

$X \quad$ numerical input

$Y \quad$ numerical output

$\Delta R \quad$ change in resistance (ohms)

$\Delta p$ differential pressure $\left(\mathrm{kN} / \mathrm{m}^{2}\right)$

$\Delta t \quad$ sampling interval (s)

$\Omega$ ohms

$\beta \quad$ resistivity (ohms $/ \mathrm{cm}$ )

$\epsilon \quad$ strain

$\eta \quad$ efficiency

$\mu \quad$ viscosity $(\mathrm{kg} / \mathrm{m} \mathrm{s})$

$\nu \quad$ Poisson's ratio

$\xi \quad$ damping ratio

$\rho$ density $\left(\mathrm{kg} / \mathrm{m}^{3}\right)$

$\sigma \quad$ standard deviation

$\tau \quad$ time constant (s)

$\phi \quad$ phase angle

$\omega \quad$ circular frequency $(\mathrm{rad} / \mathrm{s})$, also range of a variable in chapter 3 


$$
\begin{array}{ll}
\omega_{\mathrm{c}} & \text { cut-off frequency }(\mathrm{rad} / \mathrm{s}) \\
\omega_{\mathrm{n}} & \text { natural frequency }(\mathrm{rad} / \mathrm{s}) \\
\omega_{\mathrm{d}} & \text { damped frequency }(\mathrm{rad} / \mathrm{s})
\end{array}
$$

\section{Subscripts}

o referred to standard conditions, also used to denote output

i input

ref reference quantity

$\mathrm{x}$ referred to a linear displacement

a axial

$t$ transverse

T total

\section{Prefixes}

k kilo $\left(10^{3}\right)$

$\mathrm{m} \quad \operatorname{milli}\left(10^{-3}\right)$

M mega $\left(10^{6}\right)$

$\mu \quad \operatorname{micro}\left(10^{-6}\right)$

n nanno $\left(10^{-9}\right)$

$\mathrm{p} \quad \operatorname{pico}\left(10^{-12}\right)$ 